\title{
Mixed protein-DNA gel particles for DNA delivery: Role of protein composition and preparation method on biocompatibility
}

\author{
M.C. Morán ${ }^{\mathrm{a}, \mathrm{b}, *}$, D.R. Nogueira ${ }^{\mathrm{a}}$, M.P. Vinardell ${ }^{\mathrm{a}, \mathrm{b}}$, M.G. Miguel ${ }^{\mathrm{c}}$, B. Lindman ${ }^{\mathrm{c}, \mathrm{d}}$ \\ a Departament de Fisiologia, Facultat de Farmàcia, Universitat de Barcelona, Avda. Joan XXIII, 08028 Barcelona, Spain \\ b Unidad Asociada UB-CSIC, Spain \\ ${ }^{c}$ Department of Chemistry, University of Coimbra, Rua Larga, 3004-535 Coimbra, Portugal \\ d Physical Chemistry 1, University of Lund, P.O. Box 124, 22100 Lund, Sweden
}

\section{A R T I C L E I N F O}

\section{Article history:}

Received 8 April 2013

Received in revised form 17 June 2013

Accepted 19 June 2013

Available online 28 June 2013

\section{Keywords:}

DNA gels

Particles

Size

Haemolysis

In vitro cytotoxicity

\begin{abstract}
A B S T R A C T
Mixtures of two cationic proteins were used to prepare protein-DNA gel particles, employing associative phase separation and interfacial diffusion (Morán et al., 2009a). By mixing the two proteins, we have obtained particles that displayed higher loading efficiency and loading capacity values than those obtained in single-protein systems. However, nothing is known about the adverse effects on haemocompatibility and cytotoxicity of these protein-DNA gel particles. Here, we examined the interaction of protein-DNA gel particles obtained by two different preparation methods, and their components, with red blood cells and established cells. From a haemolytic point of view, these protein-DNA gel particles were demonstrated to be promising long-term blood-contacting medical devices. Safety evaluation with the established cell lines revealed that, in comparison with proteins in solution, the cytotoxicity was reduced when administered in the protein-DNA systems. In comparison with large-sized particles, the cytotoxic responses of small-sized protein-DNA gel particles showed to be strongly dependent of both the protein composition and the cell line being the tumour cell line HeLa more sensitive to the deleterious effects of the mixed protein-based particles. The observed trends in haemolysis and cell viabilities were in agreement with the degree of complexation values obtained for the protein-DNA gel particles prepared by both preparation methods.
\end{abstract}

(c) 2013 Elsevier B.V. All rights reserved.

\section{Introduction}

A general understanding of the interactions between DNA and oppositely charged agents, and in particular of phase behaviour, has provided a basis for developing novel, DNA-based materials, including gels, membranes and gel particles (Costa et al., 2008; Lindman et al., 2009, 2010). We prepared novel DNA gel particles employing associative phase separation and interfacial diffusion. By mixing solutions of DNA (either single-(ssDNA) or double-stranded (dsDNA)) with solutions of different cationic agents, such as surfactants, proteins and polysaccharides, the possibility of forming DNA gel particles without adding any kind of cross-linker or organic solvent has been confirmed (Morán et al., 2010, 2013 and references therein).

A novel nonviral vector for gene therapy is recognised as successful if it is biocompatible, capable of interacting with DNA, able to form sufficiently small particles which can be formulated

\footnotetext{
* Corresponding author at: Departament de Fisiologia, Facultat de Farmàcia, Universitat de Barcelona, Avda. Joan XXIII, 08028 Barcelona, Spain. Tel.: +34 9340245 05; fax: +34934025901.

E-mail address: mcmoranb@ub.edu (M.C. Morán).
}

reproducibly, endocytosed, able to protect the complexed DNA from degradation during transport, and capable of delivering DNA to the target tissue in sufficient quantity (Ledley, 1996; Pack et al., 2000; Davis, 2002).

Among the different cationic agents studied, the cationic surfactants offered particularly efficient control of the properties of these DNA-based particles (Morán et al., 2007a,b) However, the cytotoxicity of quaternary ammonium surfactants is well known (Lasic, 1997). Proteins as the matrices for drug delivery particles have many advantages including biodegradability, biocompatibility, and amenability to surface modification (Kratz, 2008). Drug carriers using albumin as matrices for the delivery of small molecule drugs and biological cargos, such as plasmid DNA and siRNA, are being previously studied (Rhaese et al., 2003; Hawkins et al., 2008; Abbasi et al., 2011). However, in all cases, the presence of cationic polyelectrolytes is needed to condense the nucleic acids to efficiently mediate gene transfer (Rhaese et al., 2003; Abbasi et al., 2011).

DNA gel particles have been prepared using the cationic functionality of a cationic protein. Lysozyme has been used as carrier to form DNA gel particles by interfacial diffusion (Morán et al., 2007a) The obtained particles, however, were not able to protect the secondary structure of the condensed DNA and an important burst release stage was observed when the kinetics of DNA release from 
these protein-DNA gel particles were determined. In a recent study, two cationic proteins, lysozyme and protamine sulphate, were used as biocompatible carriers to form DNA gel particles by interfacial diffusion (Morán et al., 2009a). The particles were characterised with respect to the degree of DNA entrapment, swelling and dissolution behaviour, surface morphology, secondary structure of DNA in the particles and kinetics of DNA release, and the study demonstrated that DNA was effectively entrapped in the mixed protein solutions, protecting its secondary structure. A significant increase in the degree of effective entrapment of DNA was achieved by mixing the two proteins. The magnitude of DNA release was controlled and controlled release systems were achieved by changing the lysozyme/protamine ratio in the protein solution where particles were formed.

At a consensus conference of the European Society for Biomaterials in 1986, the word "biocompatibility" was defined as "the ability of a material to perform with an appropriate host response in a specific application". With the rapid development of biomaterials, the scope of "biocompatibility" has been widely broadened. On the basis of designing DNA gel particles for therapeutic purposes, we use biocompatibility to include the deleterious effects caused by the DNA gel particles, covering the in vitro haemolytic and cytotoxic assessments. Currently, nothing is known about the adverse effects on biocompatibility of these protein-DNA gel particles. One drawback of these DNA gel particles, in toxicological terms, is the need for a cationic compound, which may cause some cellular damage. A recent study (Morán et al., 2012) indicate, however, that the effect of the cationic surfactants can be modulated when administered in the DNA gel particles, unlike what happens in aqueous solution. This modulation is due to the strong interaction between the surfactant and the biopolymer, which leads to a very slow release of the surfactant from the vehicle.

Safety evaluation of new products or ingredients destined for human use is crucial prior to exposure. Therefore, rapid, sensitive and reliable bioassays are required in order to examine the toxicity of these substances. Established cell lines are useful alternative test systems for toxicological studies of this kind (Crespi, 1995); however, they must be chosen with care with regard to their origin (Jondeau et al., 2006). Moreover, cytotoxicity assays are among the most common in vitro endpoints used to predict the potential toxicity of a substance in a cell culture (Martinez et al., 2006). The size of particles plays an important role regarding in vitro and in vivo applications. Even particles of the same material can show completely different behaviour due to, for example, slight differences in surface coating, charge or size. The particle size determines the efficiency of cellular uptake and subsequent intracellular processing (Rejman et al., 2004).

Nano-sized materials have a high potential in technical and medical applications provided they are not toxic. Despite the significant scientific interest and promising potential, the safety of nanoparticulate systems remains a growing concern, considering that biological applications of nanoparticles could lead to unpredictable effects. The prediction of toxicity is difficult, but cytotoxicity screening, which is routinely used in drug screening, gives a good indication of potential adverse effects in cells. As a general rule, nano-sized materials show higher reactivity than bulk materials of the same composition. Size, surface charge, and hydrophobicity interact in complex ways and have a pronounced influence on biocompatibility. Aggregation in physiological fluids is often observed. Therefore, toxicity data must be interpreted in the context of the physicochemical characteristics of the nano-sized materials (Fröhlich et al., 2012).

Currently, there are no specific testing requirements for nanotechnology products, and therefore, researchers took liberal approaches to studying toxicity (Boverhof and David, 2010; Robbens et al., 2010). Moreover, it is worth noting that, because
Table 1

Composition (w/w) of the DNA carrier systems expressed as LS/PS ratio.

\begin{tabular}{ll}
\hline System & LS/PS $(w / w)$ \\
\hline LS & $100 / 0$ \\
LSPS15 & $15 / 85$ \\
LSPS30 & $30 / 70$ \\
LSPS50 & $50 / 50$ \\
LSPS70 & $70 / 30$ \\
LSPS85 & $85 / 15$ \\
PS & $0 / 100$ \\
\hline
\end{tabular}

of the expense of animal testing in toxicology and pressure from both the general public and government to develop alternatives to in vivo testing, in vitro cell-based models may be more attractive for preliminary testing of nanomaterials (Hillegass et al., 2009).

In this context, the purpose of the present study was to prepare and characterise the haemocompatibility of and cytotoxicity response to protein-DNA gel particles formed by mixing double-stranded DNA (dsDNA) with lysozyme/protamine sulphate mixtures using two different approaches. The interaction of these protein-DNA gel particles and their components with erythrocytes, non-tumour (3T3 fibroblast) and tumour (HeLa) cell lines is described, using the imposed variations in protein composition and the size of the final particles, as a consequence of the different preparation method, as controlling parameters.

\section{Experimental}

\subsection{Materials}

The sodium salt of deoxyribonucleic acid (DNA) from salmon testes with an average degree of polymerisation of $\approx 2000$ base pairs (bp) was purchased from Sigma and used as received. The DNA concentrations were determined spectrophotometrically, assuming that for an absorbance of 1 at $260 \mathrm{~nm}$, a solution of dsDNA has a concentration of $50 \mu \mathrm{g} \mathrm{mL}^{-1}$ (Sambrook et al., 1989). All DNA concentrations are given in molarity per phosphate group, i.e., molarity per negative charge. The absorbance ratios at 260 and $280 \mathrm{~nm}$ of the stock solutions were found to be between 1.8 and 1.9, which suggested the absence of proteins (Saenger, 1984). Lysozyme from chicken egg white (LS), with a molecular mass of $14.3 \mathrm{kDa}$, protamine from salmon in the sulphate salt (PS), with a molecular mass of $5.1 \mathrm{kDa}$, and Tris base were purchased from Sigma and used as received. $\mathrm{N}, \mathrm{N}, \mathrm{N}^{\prime}, \mathrm{N}^{\prime}$-tetramethylacridine-3,6-diamine (acridine orange (AO)) was supplied by Molecular Probes (Invitrogen).

\subsection{Particle preparation}

The dsDNA stock solutions were prepared in $10 \mathrm{mM} \mathrm{NaBr}$ to stabilise the DNA secondary structure in its native B-form conformation. LS, PS, or mixtures of both were dissolved in a PBS buffer ( $\mathrm{pH}$ 7.4). Table 1 summarises the composition of the protein systems studied.

\subsubsection{Protein-DNA gel particles prepared by the dropwise addition method}

Particles were prepared at a DNA and protein system ratio equal to $1, R=[\mathrm{DNA}] /[P+]$, where $[P+]$ is the concentration of the corresponding protein system (concentrations determined per charge). In all cases, [DNA] was equal to $60 \mathrm{mM}$. DNA solutions were added dropwise via a 22-gauge needle into gently agitated protein solutions $(2 \mathrm{~mL})$. Under optimal conditions, droplets from DNA solutions instantaneously gelled into discrete particles upon contact with the protein solution. Thereafter, the particles were equilibrated in the solutions for a period of $2 \mathrm{~h}$ at room temperature. After this period, the particles formed were separated by filtration 
through a G2 filter and washed with $5 \times 8 \mathrm{~mL}$ PBS to remove excess salt.

\subsubsection{Protein-DNA gel particles prepared by the nebulisation method}

Particles were prepared at a DNA and protein system ratio equal to 1 . In this case, [DNA] was equal to $2.5 \mathrm{mM}$. Higher concentrations of DNA produced high-viscosity solutions, rendering them inconvenient systems for the nebulisation process. The Comp Air NE-28-E nebuliser (Omrom) employed enabled the generation of very fine droplets/aerosols with a MMAD (mass median aerodynamic diameter) of $2.8 \mu \mathrm{m}$ for NaF solution, independently measured at SolAero Ltd., Canada, by Dr. John Dennis, according to EN 13544-1. DNA solutions were nebulised and added to gently agitated protein solutions (5 mL).

\subsection{Interaction with erythrocytes}

\subsubsection{Preparation of red blood cell suspensions}

Rat blood was obtained from anaesthetised animals by cardiac puncture and drawn into tubes containing EDTA. This procedure was approved by the Ethical Committee for Animal Research of the University of Barcelona. Serum was removed from the blood by centrifugation at $3000 \mathrm{rpm}$ (Megafuge $2.0 \mathrm{R}$ Heraeus Instruments) at $4{ }^{\circ} \mathrm{C}$ for $10 \mathrm{~min}$, and subsequent suction. The red blood cells were then washed three times at $4{ }^{\circ} \mathrm{C}$ by centrifugation at $3000 \mathrm{rpm}$ with isotonic saline PBS solution, containing $22.2 \mathrm{mmol} \mathrm{L}^{-1} \mathrm{Na}_{2} \mathrm{HPO}_{4}$, $5.6 \mathrm{mmol} \mathrm{L}^{-1} \mathrm{KH}_{2} \mathrm{PO}_{4}, 123.3 \mathrm{mmol} \mathrm{L}^{-1} \mathrm{NaCl}$ in distilled water $(\mathrm{pH}$ 7.4). Following the last wash, the cells were diluted to $1 / 2$ of their volume with isotonic phosphate buffer solution (PBS) (cell density of $8 \times 10^{9}$ cell $\mathrm{mL}^{-1}$ ).

\subsubsection{Haemolysis assay}

The membrane-lytic activity of the systems was examined by haemolysis assay. Firstly, haemolytic response to the different proteins in solution was tested. Thus, a series of different volumes of protein solution ( $10 \mathrm{mg} \mathrm{mL}^{-1}$ in PBS), ranging from 10 to $200 \mu \mathrm{L}$, were placed in polystyrene tubes and an aliquot of $25 \mu \mathrm{L}$ of the erythrocyte suspension was added to each tube. The final volume was $1 \mathrm{~mL}$. The tubes were incubated at room temperature for 10 min under shaking conditions. Following incubation, the tubes were centrifuged ( $5 \mathrm{~min}$ at $10,000 \mathrm{rpm}$ ). The degree of haemolysis was determined by comparing absorbance $(540 \mathrm{~nm}$ ) (Shimadzu UV-160A) of the supernatant with that of the control samples totally haemolysed with distilled water. Positive and negative controls were obtained by adding an aliquot of $25 \mu \mathrm{L}$ of erythrocyte suspension to distilled water and isotonic PBS solution, respectively.

In the case of the protein-DNA systems, two kinds of experiments were carried out. Either the individual protein-DNA gel particles (dropwise addition method) or the dispersions containing the protein-DNA gel particles (nebulisation method) or the protein solutions that were used to prepare the corresponding protein-DNA gel particles were studied. In the case of protein-DNA particles obtained by the dropwise addition method, individual DNA gel particles were placed in the tubes. In the case of dispersions containing the protein-DNA gel particles obtained by the nebulisation method $(100,200$ or $300 \mu \mathrm{L}$ of the corresponding solution) or the protein solutions prior to the preparation of the corresponding protein-DNA gel particles ( $25 \mu \mathrm{L}$ of the corresponding solution) were added to each tube. In all cases, an aliquot of $25 \mu \mathrm{L}$ of erythrocyte suspension was added to each tube. The final volume was $1 \mathrm{~mL}$. The tubes were incubated at room temperature for different times (10-360 min) under shaking conditions. At the same defined times, the incubated samples were centrifuged ( 5 min at 10,000 rpm). The degree of haemolysis was determined following the same procedure as described above.

The correlation between the erythrocyte population and the haemolytic response in the presence of the particles was established by counting the number of erythrocytes on each sample using a Bürker-Türk counting chamber, covered by a cover slip and analysed by a contrast microscope (Olympus BX41). Simultaneously with the counting of the erythrocytes on each sample, studies of erythrocyte agglutination were carried out.

\subsubsection{DNA release}

Simultaneously with the haemolysis assay experiments, DNA release from the protein-DNA gel particles was determined. To this end, individual DNA gel particles were placed in the tubes and isotonic PBS solution was added to a final volume of $1 \mathrm{~mL}$. The tubes were incubated at room temperature for the same defined times as in the case of the haemolysis assay experiments, under shaking conditions. The concentration of dsDNA released into the supernatants was determined by using the NanoPhotometer ${ }^{\mathrm{TM}}$ (Implen).

\subsubsection{Protein release}

Furthermore, protein release from the protein-DNA gel particles was determined. To this end, individual DNA gel particles were placed in the tubes and isotonic PBS solution was added to a final volume of $1 \mathrm{~mL}$. The tubes were incubated at room temperature for the same defined times as in the case of the haemolysis assay experiments, under shaking conditions. Following incubation, the concentration of solubilised protein in the supernatants was determined using the Bio-Rad Protein Assay, based on the method described by Bradford (1986). This involves the addition of an acidic dye to the protein solution and subsequent measurement at $595 \mathrm{~nm}$ with a spectrophotometer. Comparison with a standard curve provides a relative measurement of protein concentration.

\subsection{Cell culture}

The murine Swiss albino 3T3 fibroblast cell line and the human epithelial carcinoma HeLa cell line were grown in DMEM medium ( $4.5 \mathrm{~g} \mathrm{~L}^{-1}$ glucose) supplemented with $10 \%(\mathrm{v} / \mathrm{v}) \mathrm{FBS}, 2 \mathrm{mM} \mathrm{L}-$ glutamine, $100 \mathrm{U} \mathrm{mL}^{-1}$ penicillin and $100 \mu \mathrm{g} \mathrm{mL}^{-1}$ streptomycin at $37^{\circ} \mathrm{C}, 5 \% \mathrm{CO}_{2}$. The $3 \mathrm{~T} 3$ and HeLa cells were routinely cultured in $75 \mathrm{~cm}^{2}$ culture flasks and were trypsinised using trypsin-EDTA when the cells reached approximately $80 \%$ confluence.

\subsubsection{Cytotoxicity assays}

The cytotoxic effect of the systems was measured by tetrazolium salt MTT assay (Mosmann, 1983). 3T3 and HeLa cells were seeded into the central 60 wells of a 96-well plate at a density of $1 \times 10^{5}$ and $5 \times 10^{4}$ cells $\mathrm{mL}^{-1}$, respectively. After incubation for $24 \mathrm{~h}$ under $5 \% \mathrm{CO}_{2}$ at $37{ }^{\circ} \mathrm{C}$, the spent medium was replaced in the wells with $100 \mu \mathrm{L}$ of fresh medium supplemented with 5\% FBS containing protein solution at the required concentration range (50-2000 $\mu \mathrm{g} \mathrm{mL}^{-1}$ ).

In the case of the protein-DNA systems, two kinds of studies were carried out. Either the individual protein-DNA gel particles (dropwise addition method) or the dispersions containing the protein-DNA gel particles (nebulisation method) or the protein solutions that were used to prepare the corresponding protein-DNA gel particles were studied. In the case of the individual protein-DNA gel particles, $100 \mu \mathrm{L}$ of fresh medium supplemented with 5\% FBS was added in each well, and then individual DNA gel particles were placed in them. In the case of the dispersion containing the protein-DNA gel particles or the protein solutions prior to the preparation of the corresponding protein-DNA gel particles, $100 \mu \mathrm{L}$ of each system diluted 1:1 in fresh medium supplemented with $5 \%$ FBS was placed in each well. 
In all cases, after $24 \mathrm{~h}$, the protein-DNA gel particles or the protein-containing medium were removed and $100 \mu \mathrm{L}$ of MTT in PBS ( $5 \mathrm{mg} \mathrm{mL}^{-1}$ ) diluted 1:10 in medium without FBS and phenol red was then added to the cells. The plates were incubated for a further $3 \mathrm{~h}$, after which the medium was removed, and the cells were washed once in PBS. Thereafter, $100 \mu \mathrm{L}$ of DMSO was added to each well to dissolve the purple formazan product. After $10 \mathrm{~min}$ on a microtitre-plate shaker at room temperature, absorbance of the resulting solutions was measured at $550 \mathrm{~nm}$ using a Bio-Rad 550 microplate reader. The effect of each treatment was calculated as a percentage of cell viability inhibition against the respective controls.

\subsection{Internalisation of AO-labelled PS-DNA gel particles}

\subsubsection{Preparation of AO-labelled PS-DNA gel particle dispersion}

AO stock solution $\left(10 \mu \mathrm{g} \mathrm{mL}^{-1}\right)$ was diluted $1: 5$ in a solution of DNA (2.5 mM). The AO-labelled PS-DNA gel particle dispersion was prepared by nebulisation of the AO-labelled DNA into a solution of protein $(2.5 \mathrm{mM})$. After formation, the particle dispersion was filtered by a centrifugal concentrator (cut-off 3000 MWCO, Vivaspin 2 ) to remove the excess of free PS and non-incorporated AO.

\subsubsection{Cellular uptake experiments}

HeLa cells $\left(5 \times 10^{4}\right.$ cells $\left.\mathrm{mL}^{-1}\right)$ were seeded into 24 -well tissue plates on Corning's circular glass cover-slips at $37^{\circ} \mathrm{C}$ and $5 \% \mathrm{CO}_{2}$ atmosphere. After incubation for $24 \mathrm{~h}$, the purified AO-labelled PSDNA gel particle dispersion was diluted 1:1 in medium without FBS and phenol red and then added to the cells. Untreated cells stained with AO ( $\left.1.5 \mu \mathrm{g} \mathrm{mL}^{-1}\right)$ in DMEM medium without FBS and phenol red were used as a cell control. The plates were incubated for a further $2 \mathrm{~h}$ at $37^{\circ} \mathrm{C}$ and $5 \% \mathrm{CO}_{2}$ atmosphere, after which the medium was removed, and the cells were washed four times with sterile PBS. After the final wash, the cells were fixed with $4 \%(v / v)$ paraformaldehyde in PBS for $15 \mathrm{~min}$ at room temperature and were washed twice with PBS.

Individual cover-slips were then mounted on clean glass slides with Prolong ${ }^{\circledR}$ Gold antifade reagent (Invitrogen). Both contrast and fluorescence images were acquired with a Olympus BX41 microscope equipped with a UV-mercury lamp (100 W Ushio Olympus) and a filter set type MNIBA3 (470-495 nm excitation and $505 \mathrm{~nm}$ dichromatic mirror) Images were digitised on a computer through a video camera (Olympus digital camera XC50) and were analysed with an image processor (Cell B analysis).

\section{Results}

\subsection{Haemolytic assessments}

\subsubsection{Haemolysis induced by proteins in solution}

The haemolytic activity of both proteins at different $\mathrm{pH}$ was determined according to concentration. In these experiments, haemolysis was determined at a fixed time (after $10 \mathrm{~min}$ of incubation) in the presence of protein concentrations in the range of $100-2000 \mu \mathrm{g} \mathrm{mL}^{-1}$. The haemolysis assay showed that both proteins were non-haemolytic in nature. The haemolytic potential of a material is defined as the measure of the extent of haemolysis that may be caused by the system when it comes into contact with blood. At pH 7.4, both proteins were found to be non-haemolytic, the extent of haemolysis being lower than the permissible level of 5\% (Rao and Sharma, 1997; Lv et al., 2007; He et al., 2009; Venkatesan et al., 2011). For the lowest concentration, the maximum haemolysis values were $0.3 \%$ and $0.8 \%$ for the LS and PS proteins, respectively. At the highest concentration, the value increased to $0.5 \%$ in the case of LS, and $1.7 \%$ in the case of PS. In
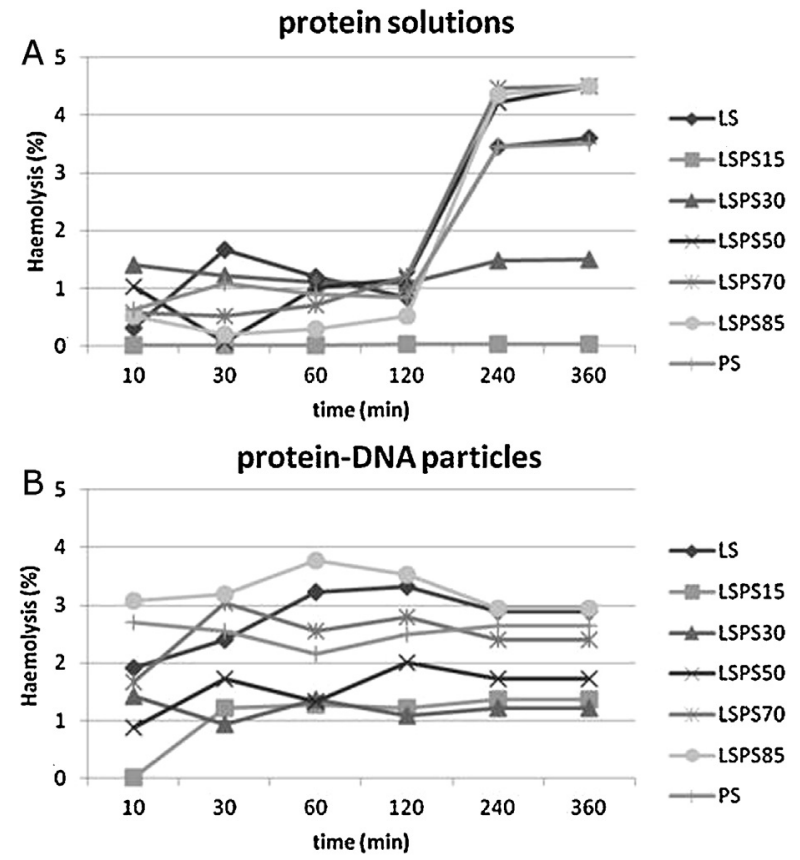

Fig. 1. Protein solutions (A) and protein-DNA gel particles (B) induced haemoglobin release from rat erythrocytes as a function of time.

both cases, haemolysis was negligible at the highest concentration assayed $\left(2000 \mu \mathrm{g} \mathrm{mL}^{-1}\right)$.

No significant differences were observed in the haemolytic response when varying the $\mathrm{pH}$ of the buffer solution from 7.4 to 5.4. The isoelectric point ( $\mathrm{p} I$ ) value of the LS and PS proteins was almost equal to 11 and 12 , respectively, conserving their cationic character under the studied $\mathrm{pH}$ interval. Although results on $\mathrm{pH}$ dependence of LS net charges demonstrated that the charges varied between +8.5 at pH 5.5 to +7 at pH 8 (Desfougères et al., 2010), there was no strong alteration in the haemolytic responses. To the author's knowledge, nothing has been reported on $\mathrm{pH}$ dependence of PS net charges.

The observed behaviour differed strongly from that observed, for instance, for surfactants in solution (Morán et al., 2012). In this kind of system, haemolysis varied with the surfactant concentration in a sigmoidal manner, until reaching total haemolysis.

\subsubsection{Haemolysis induced by protein-DNA gel particles}

3.1.2.1. Protein-DNA gel particles prepared by the dropwise addition method. In order to evaluate the effect of protein-DNA complexation on the corresponding haemolytic response, both the corresponding protein-DNA gel particles as well as the protein solutions at the conditions used to prepare the protein-DNA gel particles, were incubated with the erythrocyte suspensions for different lengths of time (ranging from 10 to $360 \mathrm{~min}$ ) (Fig. 1). Using this approach, the haemolytic response to the protein solutions corresponding to the conditions used to prepare the protein-DNA gel particles, prior to interaction with the DNA drops, would provide us with information about the maximum haemolytic response expected for these conditions. As regards the different incubation times, it was expected that the haemolytic response to the protein solutions would not alter over time. However, long incubation periods could affect the stability of the protein-DNA gel particles, promoting the release of the protein into the solution and altering the haemolytic response.

Studies of the different protein systems in solution demonstrated that the haemolytic response was weakly dependent on the protein composition in which particle formation took place 

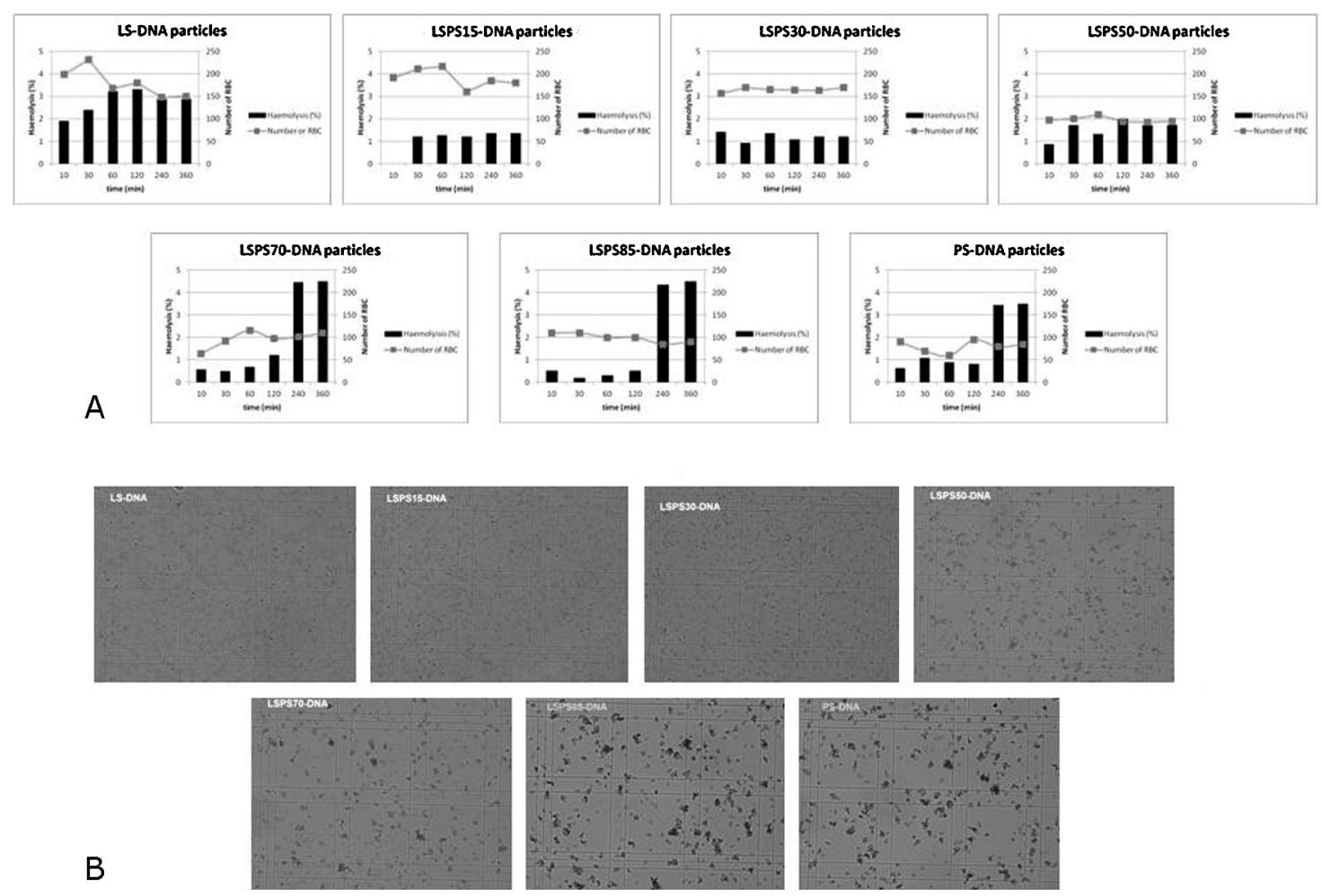

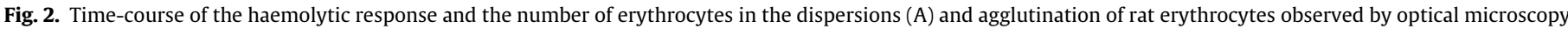
after 60 min of incubation with the protein-DNA gel particles (B).

(Fig. 1A). The obtained profiles showed haemolytic percentages that remained constant between 10 and 120 min, increasing by only $5 \%$ by the end of the experiment $(360 \mathrm{~min})$. Note that the protein concentrations assayed in these studies $(60 \mathrm{mM}$, concentrations ranged between $3 \times 10^{4}$ and $2 \times 10^{5} \mu \mathrm{g} \mathrm{mL}^{-1}$ in the case of pure protein systems) were well above the $2 \times 10^{3} \mu \mathrm{g} \mathrm{mL}^{-1}$ assayed in the case of pure protein systems in solution (see above). Our results demonstrated that both of the pure proteins, LS and PS, as well as the mixtures at the imposed compositions (see Table 1 ) were non-haemolytic in nature.

Individual protein-DNA gel particles incubated in the erythrocyte dispersion for periods of time ranging between 10 and $360 \mathrm{~min}$ demonstrated no time-dependence in the haemolysis response. In all cases, the percentages of haemolysis were lower than $3 \%$ (Fig. 1B).

3.1.2.1.1. Relationship between the degree of haemolysis, number of erythrocytes and agglutination of erythrocytes. Determination of haemolytic properties is one of the most common tests in studies of particle interaction with blood components. Interpreting the results of these studies is complicated due to variability in experimental approaches and a lack of universally accepted criteria for determining the test-result validity. Most in vitro studies of particle-induced haemolysis evaluate the percentage of haemolysis by spectrophotometrically detecting plasma-free haemoglobin derivatives after incubating the particles with blood and then separating undamaged cells by centrifugation. However, some particle interference due to haemoglobin precipitates adsorbed with the particles on centrifugation has been reported, yielding a false negative result (Dobrovolskaia et al., 2008).

To avoid these false negative results in the haemolytic response of these protein-DNA particles, the evolution of both haemolytic activity and the number of erythrocytes in the dispersions for each time were determined simultaneously. Fig. 2A shows the results. There is a good relationship between the degree of haemolysis found and the number of erythrocytes. Low values of haemolytic responses correspond to a high number of erythrocytes in the corresponding dispersion; and an increase in haemolysis corresponds to a decrease in the number of erythrocytes. Thus, the effect of adsorbed haemoglobin on the particles can be considered negligible.

There is, however, another point to be note. Starting for systems containing equimolar amount of both proteins or higher PS content, a strong decrease of the number of erythrocytes was observed, even for the shortest incubation time. This decrease, corresponding to a half of the initial number of erythrocytes was independent of the haemolytic responses. This fact can be correlated with the agglutination of the erythrocytes, which became visible for the erythrocyte dispersions incubated with these systems (Fig. 2B).

3.1.2.1.2. Relationship between the DNA released and the degree of haemolysis. Previous work in our lab has demonstrated the potential application of these protein-DNA gel particles in the controlled encapsulation and release of DNA (Morán et al., 2009a). The magnitude of the DNA release was controlled and controlled release systems were achieved by changing the LS/PS ratio in the protein solution where particles were formed.

Nevertheless, it was of major interest in this study to characterise these DNA gel particles, considering their kinetics of DNA release and the induced haemolytic response simultaneously. The release profiles of DNA from the protein-DNA gel particles in PBS buffer ( $\mathrm{pH} 7.4$ ) prepared with different protein compositions were monitored simultaneously with the haemolysis response induced by these protein-DNA gel particles in the same buffer solution.

The values for both the amount of DNA release and the percentage of haemolysis for each composition after 360 min of incubation have been plotted in Fig. 3. It can be seen that the amount of DNA released, for an almost constant haemolytic response, was strongly dependent on the protein composition in which particle formation took place. In the range of LS/PS studied, the amount of DNA that was released varied from $100 \mu \mathrm{g} \mathrm{mL}^{-1}$ in the case of the pure LS system to $3 \mu \mathrm{g} \mathrm{mL}^{-1}$ in the systems containing the PS protein. Further 

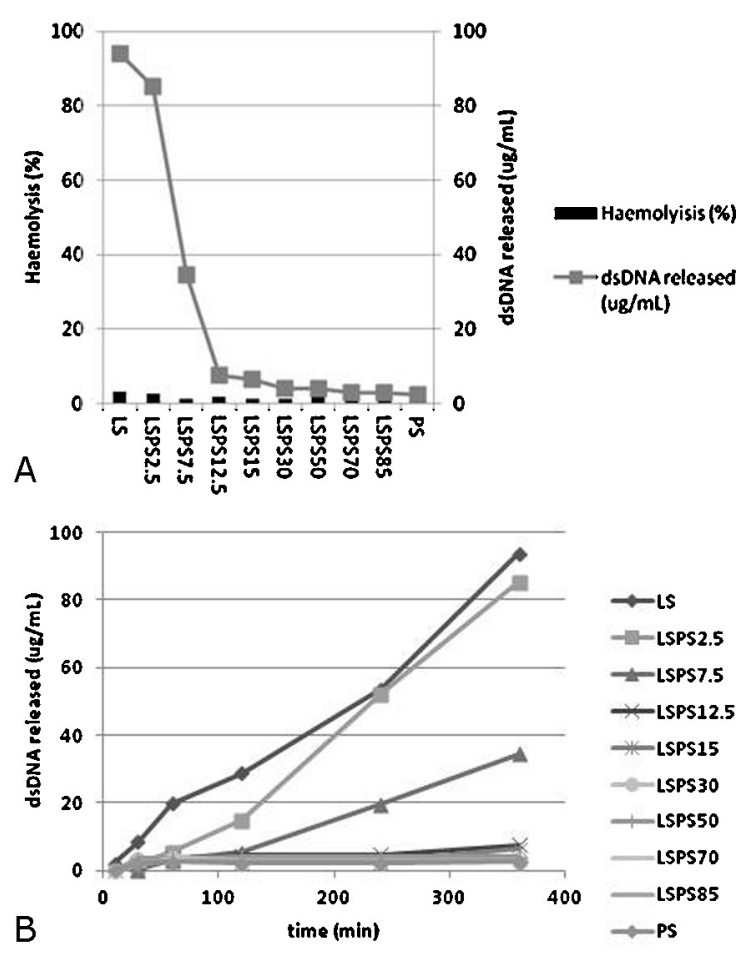

Fig. 3. Protein-DNA particle-induced haemoglobin release from rat erythrocytes and DNA release after $360 \mathrm{~min}$ of incubation (A) and kinetics of DNA release profiles for the studied protein-DNA particles (B).

studies demonstrated that intermediate compositions between the pure LS system and the LSPS15 system promoted a more progressive decrease in DNA release with a similar haemolytic response (Fig. 3B).

3.1.2.1.3. Determination of protein content and complexation stoichiometries. The observed differences in DNA release can be explained by differences in protein-DNA complexation in these systems. To this end, the amount of protein released in the media by the end of the experiment was determined (Fig. 4, black bars). The protein:DNA ratio in the particles was determined from the protein released by the particles and the amount of DNA released into the media (see Fig. 3 line plots and Fig. 4, grey bars). Fig. 4A shows the evolution of the protein:DNA ratio according to protein composition.

This protein-DNA ratio increased strongly from the pure LS system to the pure PS system. This different distribution can be correlated with differences in the gelation process during particle formation. It was expected that a homogeneous gelation would give rise to homogeneous structures (solid particle) whereas a more inhomogeneous gelation process would form core-shell particles (Morán et al., 2010).

In the present study, the stoichiometries obtained corroborated that the presence of PS favoured the formation of solid particles. This model was supported by visual inspection, in which translucent and opaque/condensed particles were obtained (Fig. 4B).

3.1.2.2. Protein-DNA gel particles prepared by the nebulisation method. In previous studies in our lab, we have prepared nano/micro-sized DNA gel particles by nebulisation of DNA solutions (either single- (ssDNA) or double-stranded (dsDNA)) into an oppositely charged surfactant or protein solution (Morán et al., 2009b). The size and size distribution of the particle populations were investigated by means of fluorescence microscopy (FM), photon correlation spectroscopy (PCS) and scanning electron microscopy (SEM). FM studies suggest that the formation of the particles was carried out with conservation of the secondary structure of the nucleic acid molecules. SEM on freeze-dried and Au-shadowed samples showed a distribution of virtually spherical particles. Although the particle suspensions were investigated without further purification it was found that, in addition to the size of the initial DNA droplets, the cationic agent is a controlling parameter of the particle size. LS-DNA gel particles showed diameters around $10 \mu \mathrm{m}$ whereas the size of PS-DNA was around $400 \mathrm{~nm}$.

In the present study, protein-DNA gel particles from mixed protein systems have been prepared by the nebulisation method for the first time. The assayed conditions correspond to a half of the previous studied concentrations (Morán et al., 2009b). Mixed protein-DNA particles prepared with proteins with very different molecular weight (LS with a molecular mass of $14.3 \mathrm{kDa}$ and PS with a molecular mass of $5.1 \mathrm{kDa}$ ) made particularly difficult to use centrifugal concentrators with a suitable cut-off to efficiently remove both proteins. For this reason, these particle dispersions have been studied without further purification.

The haemolytic activity of the protein-DNA gel particles prepared by the nebulisation method was determined. For thus, several volumes $(100-300 \mu \mathrm{L})$ of the dispersions containing the protein-DNA gel particles were incubated in the erythrocyte dispersion for periods of time ranging between 10 and $360 \mathrm{~min}$ and haemolysis was determined. The obtained results demonstrated no time-dependence in the haemolysis response. In all cases, the percentages of haemolysis were lower than $1 \%$ (data not shown).

The protein concentrations assayed in these studies $(2.5 \mathrm{mM}$, concentrations ranged between $3 \times 10^{3}$ and $2 \times 10^{4} \mu \mathrm{g} \mathrm{mL}^{-1}$ in the case of pure protein systems) were one order of magnitude lower than those assayed in the case of protein-DNA gel particles obtained by the dropwise addition method, where haemolytic responses were always lower than 3\% (see Fig. 1B).

\subsection{Cytotoxic assessments}

Cytotoxicity plays a critical role in the efficiency of the delivery vectors. In order to deliver the DNA into the cells, the cationic particles bind to the cell surface by electrostatic interaction, promote endocytosis and release the genetic material inside the cell. Unfortunately, while high concentrations of the delivery agents imply an increased chance of the DNA penetrating the cell nucleus, they can also interfere with physiological processes within the cell, inducing cell death. Thus, present research is aimed at designing gene delivery agents that are able to deliver DNA into the cells with minimal toxicity (Rao et al., 2007).

\subsubsection{Cytotoxicy induced by proteins in solution}

Assessing the capacity of live cells to metabolise a tetrazolium colourless salt to a blue formazan (MTT assay) is one of the most common methods used to perform indirect measurements of cell viability. Dose-response curves for each protein, determined by MTT assays using tumour cell line HeLa and non-tumour cell line 3T3 fibroblasts, are given in Fig. 5. The cytotoxicity assays were performed in the concentration range 50 and $2000 \mu \mathrm{g} \mathrm{mL}^{-1}$. Although it is thought that proteins are biocompatible and nontoxic compounds, our results have revealed that, as with other cationic derivatives, LS and PS displayed concentration-dependent toxicity towards cells in vitro. LS showed low cytotoxicity towards 3T3 cells, which displayed viability in the range $81 \%$ to $100 \%$ as determined by the MTT assay (Fig. 5A) at the tested protein concentration range. In the case of PS, viability changed from $7 \%$ to $100 \%$ according to the concentration. The corresponding $\mathrm{IC}_{50}$ values were $140 \mu \mathrm{g} \mathrm{mL}^{-1}$ and $>2000 \mu \mathrm{g} \mathrm{mL}^{-1}$ for PS and LS, respectively.

Analogous studies were carried out with the tumour cell line HeLa. The response to these two proteins was very similar to that of the 3T3 cell line, as can be seen in Fig. 5B. The corresponding 

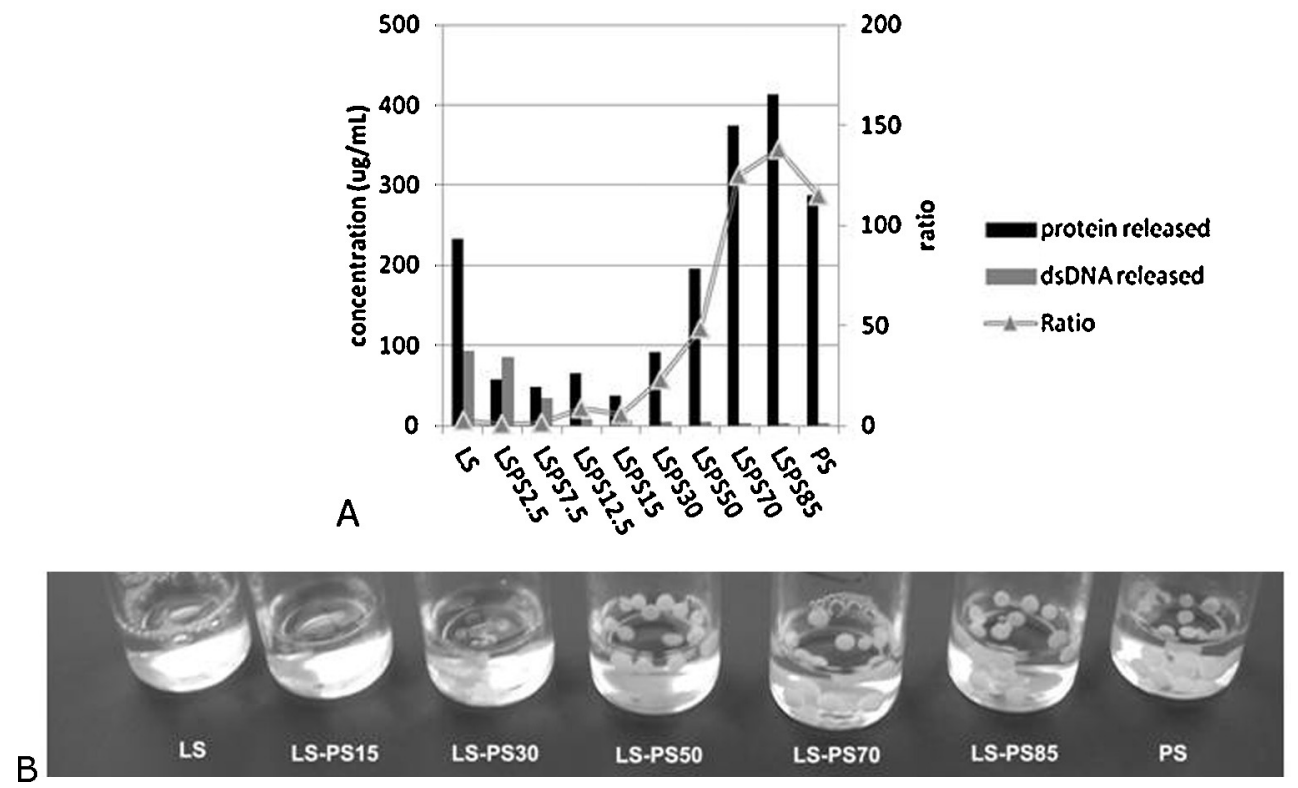

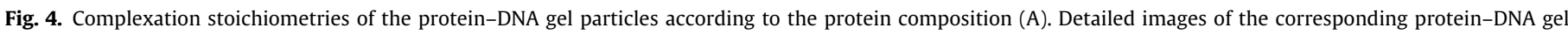
particles (B).

Adapted from Morán et al. (2009a).

$\mathrm{IC}_{50}$ values were $250 \mu \mathrm{g} \mathrm{mL} \mathrm{m}^{-1}$ and $>2000 \mu \mathrm{g} \mathrm{mL} \mathrm{L}^{-1}$ for PS and LS, respectively.

\subsubsection{Cytotoxicity in vitro induced by protein-DNA gel particles}

3.2.2.1. Protein-DNA gel particles prepared by the dropwise addition method. It was of great interest in this study to characterise these DNA gel particles considering the cytotoxic response they induced. Fig. 6 shows the cytotoxic response of 3T3 and HeLa cell lines treated with both the protein-DNA gel particles and the corresponding protein solutions, determined by MTT assay. Cell viabilities of up to $80 \%$ were observed in almost all compositions
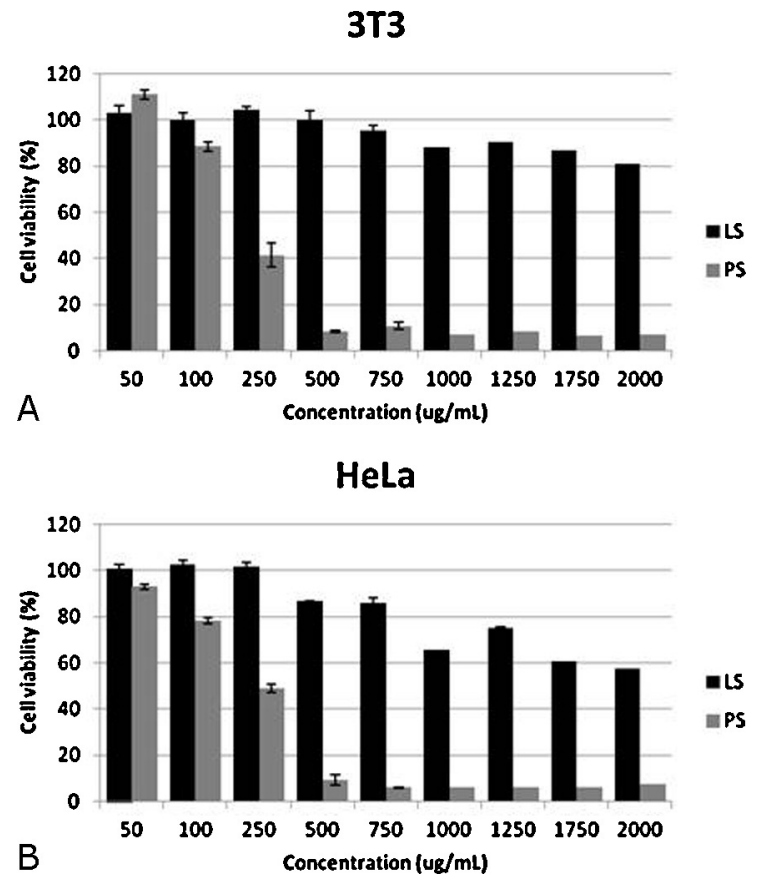

Fig. 5. Concentration-dependent relative viabilities of 3T3 cells (A) and HeLa cells (B) treated with LS and PS for $24 \mathrm{~h}$ determined by MTT assay. The data correspond to the average of three independent experiments \pm standard deviation. when the cytotoxicity of the corresponding protein-DNA gel particles was determined in both cell lines (Fig. 6A). However, relative viabilities were always lower than $10 \%$ when 3 T3 cells were incubated in the presence of pure and mixed protein systems. Similar

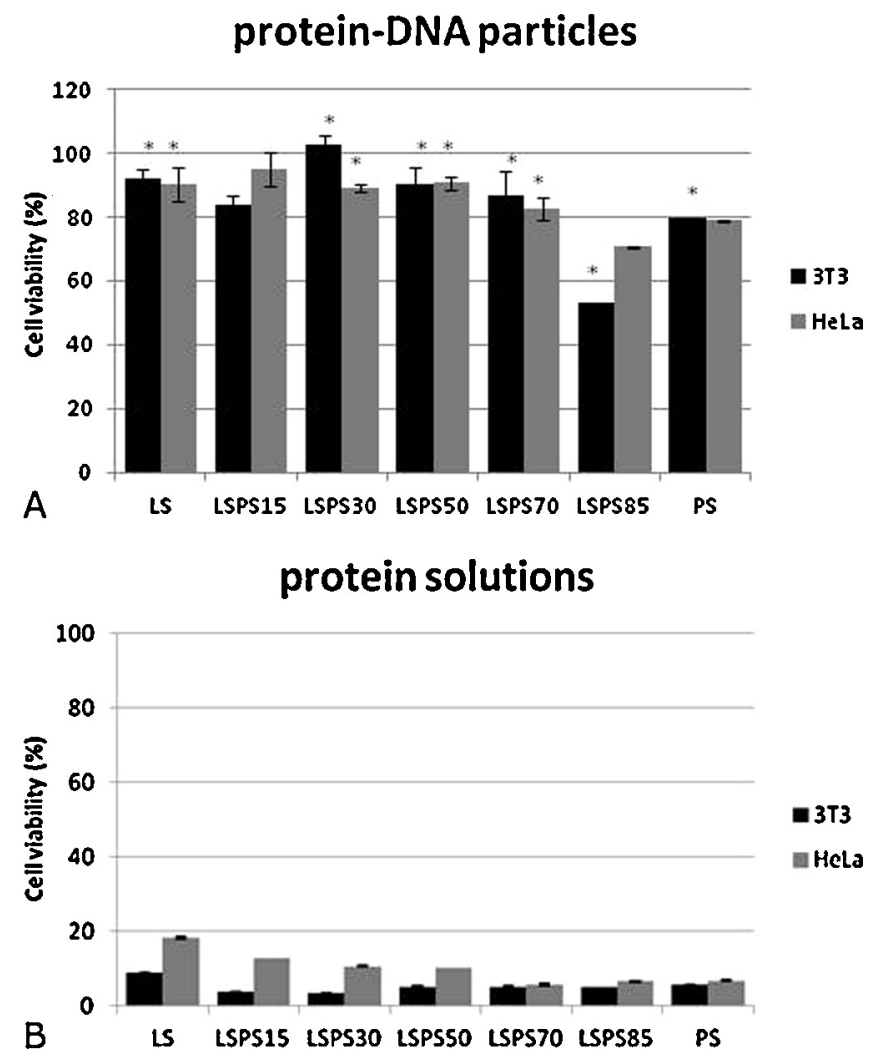

Fig. 6. Relative viabilities of $3 \mathrm{~T} 3$ and HeLa cells treated with individual protein-DNA gel particles (A) and the corresponding protein solutions (B) for $24 \mathrm{~h}$, determined by MTT assay. The data correspond to the average of three independent experiments \pm standard deviation. In all cases, significant differences $(p<0.05)$ between 3T3 and HeLa for the same conditions were found. *Significantly different $(p<0.05)$ from the corresponding protein solution. 
protein-DNA particles
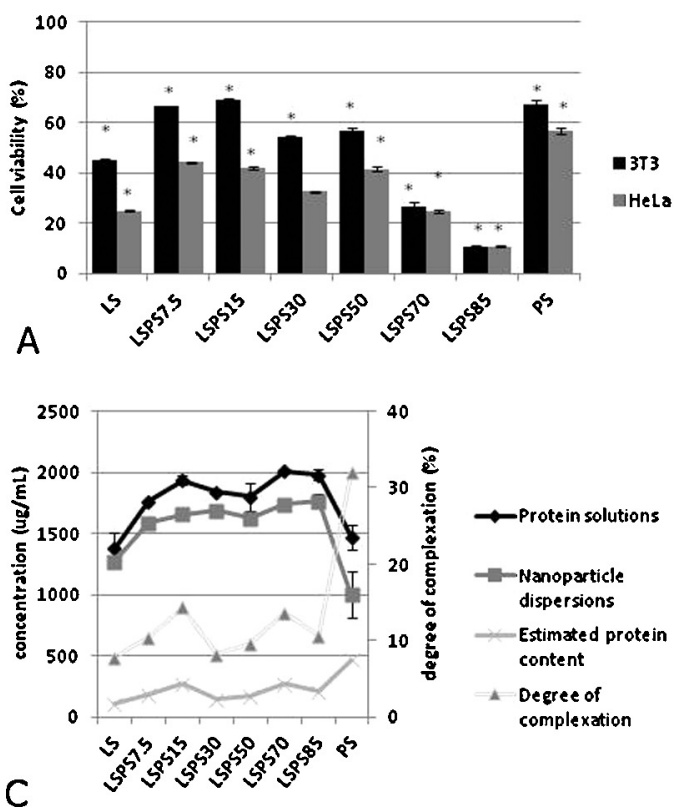

protein solutions

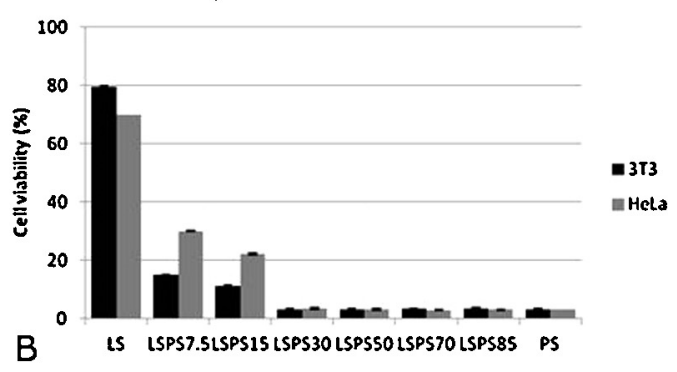

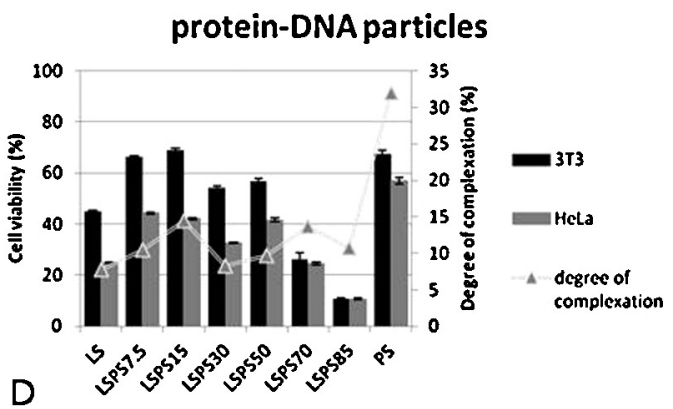

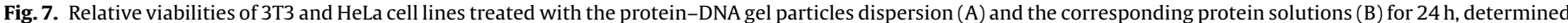

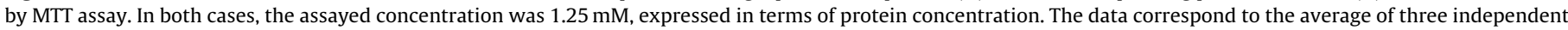

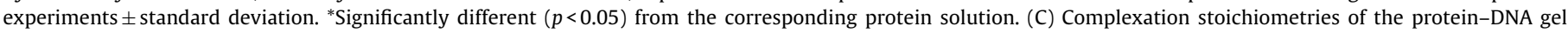

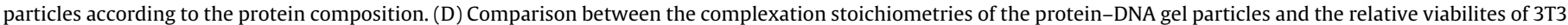
and HeLa cell lines according to protein composition.

results were obtained for the HeLa cell line. In this case, cell viabilities increased step-wise to $20 \%$ (Fig. 5B).

3.2.2.2. Protein-DNA gel particles prepared by the nebulisation method. Although the molecular details of the mechanism by which cationic carriers mediate DNA delivery are still poorly understood, current evidence supports the hypothesis that cationic lipid-DNA complexes enter cells by means of endocytosis. Often, the particle size ranges from $100 \mathrm{~nm}$ to over $1 \mu \mathrm{M}$, and evidently, the efficiency of cellular uptake and subsequent intracellular processing, may depend on particle size (Rejman et al., 2004).

Using the MTT assay, the cytotoxic effect of these systems was determined. Fig. 7 shows the relative cytotoxicity of the protein-DNA gel particles and the corresponding protein solutions towards the 3T3 and HeLa cell lines. In both cases, the assayed concentration was $1.25 \mathrm{mM}$, expressed in terms of protein concentration. Note that the LSPS7.5 composition has been also included; considering the results obtained in the haemolysis vs. DNA release section (see Fig. 3B).

From Fig. 7A it can be deduced that 3T3 cells exhibited cell viabilities that can be modulated from 10 to $70 \%$ according to the protein composition in the protein-DNA gel particles. It is interesting to note that the presence of a small quantity of PS produced a marked improvement in cell viability compared to the pure LS system, and a small proportion of LS in the PS system produced a marked reduction in the cell viability obtained in comparison with pure PS. A parallel trend was observed when the cytotoxicity of these systems was assayed with the HeLa cell line. However, relative viabilities of the 3T3 cell line were always higher than those observed in the case of the HeLa cell line, and the tumour cell line HeLa appeared to be more sensitive to the deleterious effects of the protein-based particles than $3 \mathrm{~T} 3$ fibroblasts.

In order to compare, the relative viabilities obtained with the corresponding protein solutions have also been plotted (Fig. 7B). Cell viability in the 3T3 cell line was strongly dependent on the protein composition, ranging from a maximum value of around
$80 \%$ with pure LS to minimum values of around $10 \%$ for systems containing the PS protein.

The observed differences in cytotoxicity may be correlated with differences in protein-DNA complexation in these systems. Consequently, we determined the initial amount of protein in the media, as well as the amount of protein remaining in the dispersion containing the protein-DNA gel particles formed by the nebulisation method. From these values, the degree of complexation in the different systems was determined. Fig. 7C shows the evolution of the degree of complexation according to the LS/PS ratio. In the case of the protein-DNA gel particles, it was expected that the higher the degree of complexation, the smaller the amount of protein that would be released in solution, an amount which would be able to interact with the cells and reduce their viability. Independently of the cell line response, the differences in the degree of complexation were in agreement with the observed trend in cell viabilities (Fig. 7D).

3.2.2.2.1. Relative viabilities of tumour and non-tumour cell lines. Further data on the concentration-dependent cytotoxicity of these small-sized protein-DNA gel particles was obtained by examination of the relative cytotoxicity of several dilutions of the corresponding dispersions (Fig. 8). Note that the concentrations are expressed in terms of protein concentration, given in mM. The highest concentration corresponded to the conditions shown in Fig. 7A. By fitting the curves in Fig. 8, it was possible to determine the $\mathrm{IC}_{50}$ of these protein-based DNA carriers (Table 2).

It can be seen from the $\mathrm{IC}_{50}$-values that the two cells lines showed markedly different sensitivity to the cytotoxic effects of these small-sized protein-DNA particles. Except in the case of the pure systems, which displayed identical cytotoxicity in both cell lines, the tumour cell line HeLa appeared to be more sensitive to the deleterious effects of the mixed protein-based particles than 3T3 fibroblasts (significant differences between 3T3 and HeLa for the same conditions are indicated in Table 2 with an asterisk).

3.2.2.2.2. Internalisation of AO-labelled PS-DNA gel particles. The ability of these particles to effectively cross biological barriers, 


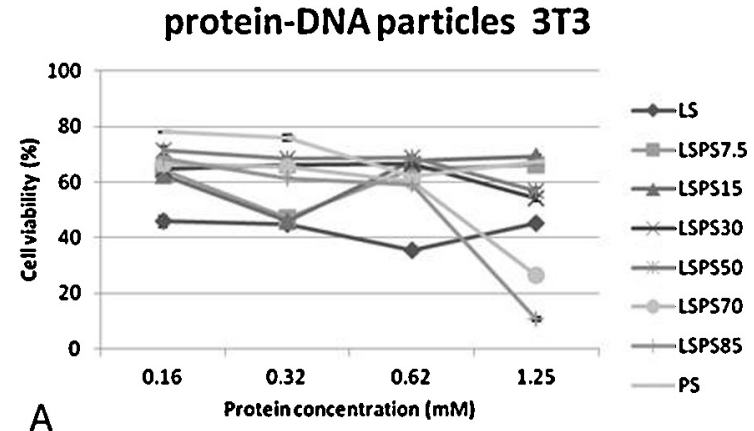

protein-DNA particles HeLa

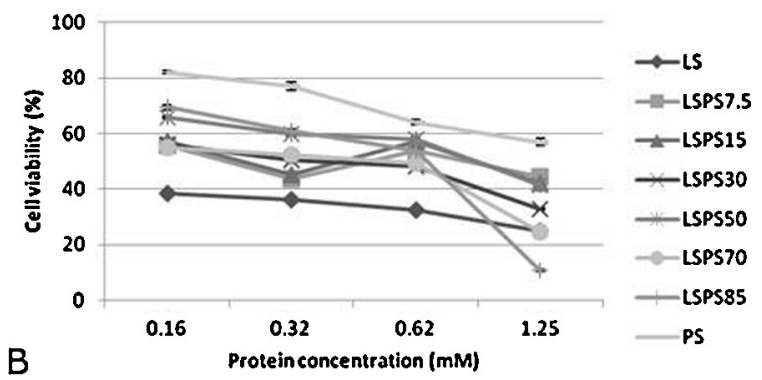

Fig. 8. Concentration-dependent relative viabilities of $3 T 3(\mathrm{~A})$ and HeLa cells (B) treated with the protein-DNA gel particles prepared by the nebulisation method for $24 \mathrm{~h}$, determined by MTT assay. The data correspond to the average of three independent experiments \pm standard deviation.

which would allow their use in the delivery of DNA, was evaluated. PS-DNA gel particles, which showed both suitable particle size and minimum cytotoxic responses, were chosen for this kind of experiments. For this purpose, AO-labelled PS-DNA gel particles were prepared and the particle uptake by HeLa cells was assayed. In general, particles exposed to cells in the absence of serum have a stronger adhesion to the cell membrane and higher internalisation efficiency, in comparison to what is observed in medium containing
Table 2

Cytotoxic properties of the protein-based DNA carrier systems prepared by the nebuliser method. Note that the $\mathrm{IC}_{50}$ values are given in terms of protein concentration (mM).

\begin{tabular}{lcc}
\hline System & $3 \mathrm{~T}^{\mathrm{IC}} \mathrm{IC}_{50}(\mathrm{mM})$ & HeLa IC \\
\hline LS-DNA & $(\mathrm{mM})$ \\
LSPS7.5-DNA $^{*}$ & $<0.16$ & $<0.16$ \\
LSPS15-DNA & $>1.25$ & 0.88 \\
LSPS30-DNA & $>1.25$ & 0.92 \\
LSPS50-DNA & $>1.25$ & 0.32 \\
LSPS70-DNA & $>1.25$ & 0.92 \\
LSPS85-DNA & 0.80 & 0.60 \\
PS-DNA & 0.75 & 0.68 \\
& $>1.25$ & $>1.25$
\end{tabular}

* Significantly different at $p<0.05$.

serum, when a preformed protein layer is present on their surface (Lesniak et al., 2012). In order to perform these studies on the most favourable conditions the experiments were carried in absence of serum. Preliminary studies on cellular uptake of protein DNA gel particles prepared with DNA solutions in the presence of the nucleic acid selective dye acridine orange demonstrated that these particles could be internalised by HeLa cells (Fig. 9D).

\section{Discussion}

A general understanding of the interaction of DNA with oppositely charged amphiphiles and polyelectrolytes provides a basis for developing novel DNA gel particles, including protein-DNA gel particles. When used as DNA carriers, understanding the interactions of these DNA gel particles with red blood cells and established cells in vitro is crucial for improving their behaviour in vivo. To this end, we examined this interaction by using erythrocytes as a model of a biological membrane system. Firstly, the haemolytic activity of these two proteins in solution was studied according to their concentration and the concentration-dependent curves were determined. It may be concluded that both proteins are non-haemolysing agents at the highest concentration assayed $\left(2000 \mu \mathrm{g} \mathrm{mL}^{-1}\right)$.
A

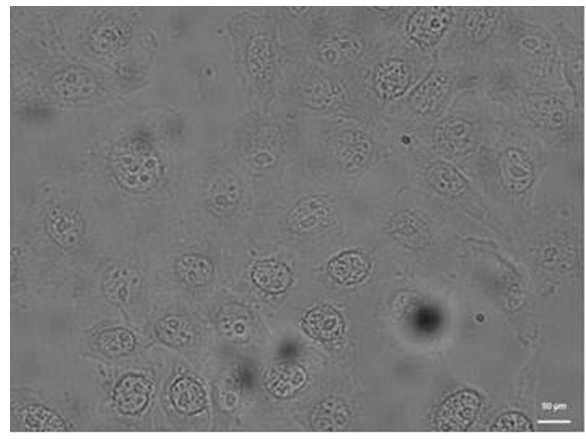

C

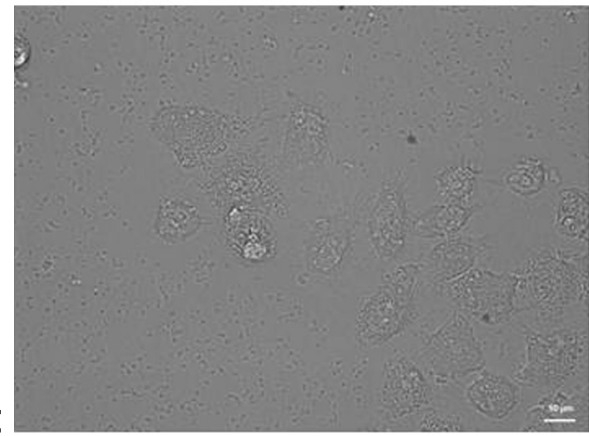

B
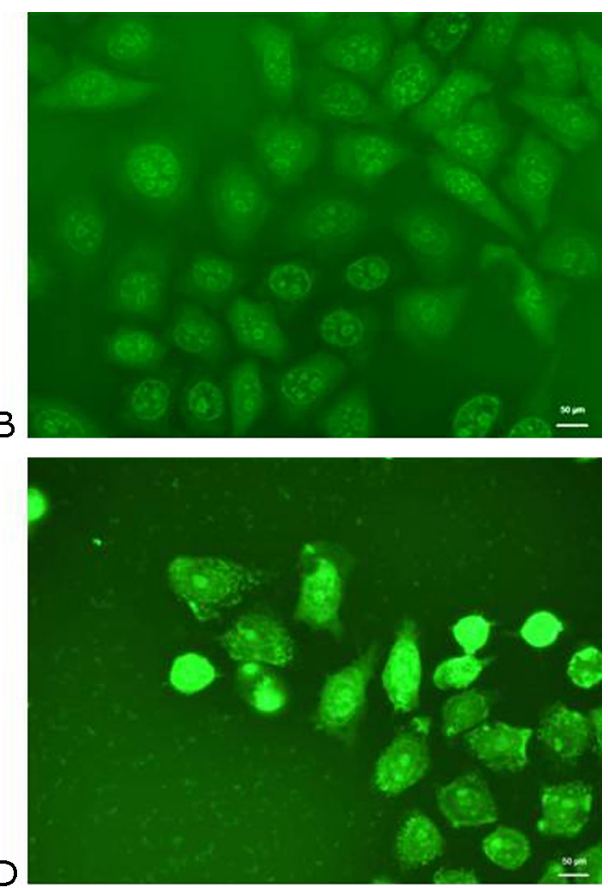

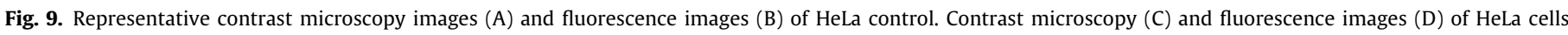
incubated during $2 \mathrm{~h}$ in the presence of PS-DNA particles. Magnification $40 \times$. 
One drawback of protein-DNA gel particles, in toxicological terms, is the need for a cationic protein, which may cause some cell damage. Our results demonstrated that both of the pure proteins, LS and PS, as well as the mixtures at the imposed compositions (see Table 1) at which particles were prepared, were non-haemolytic in nature. Studies of individual protein-DNA gel particles incubated in the erythrocyte dispersion over periods of time ranging between 10 and 360 min demonstrated no time-dependence in the haemolysis response (Fig. 1). In all cases, the percentages of haemolysis were lower than the permissible 5\% (Rao and Sharma, 1997; Lv et al., 2007; He et al., 2009; Venkatesan et al., 2011). Similar results were obtained with protein-DNA gel particles obtained by the nebulisation method. Consequently, the in vitro haemolysis results suggest that these protein-DNA gel particles show promise as long-term blood-contacting medical devices for several applications.

The agglutination induced by the protein-DNA gel particles containing equimolar amount of both proteins or higher PS content (Fig. 2) may be caused by increased binding of the particles to the erythrocyte membrane, which might deformed cells and hence decrease the repulsion among them (Li et al., 2008). This behaviour could be attributed to differences in the binding characteristics of these two proteins, with different total charge and linear charge density: LS is a globular protein that has a net charge of +9 at neutral $\mathrm{pH}$, whereas PS is a highly positively charged linear protein with an overall charge of +21 .

It was of major interest in this investigation to characterise these DNA gel particles considering their kinetics of DNA release and the induced haemolytic response simultaneously (Fig. 3). It was observed that the amount of DNA released, for an almost constant haemolytic response, was strongly dependent on the protein composition at which particle formation took place. In the range of LS/PS studied, the amount of DNA that was released varied considerably, from $100 \mu \mathrm{g} \mathrm{mL}^{-1}$ in the case of the pure LS system to almost $3 \mu \mathrm{g} \mathrm{mL}^{-1}$ in the presence of the PS protein. Achieving high incorporation efficiencies and control over release kinetics present significant challenges in the development of a novel nonviral vector for gene therapy. Previous studies (Morán et al., 2009a) demonstrated, however, that LS-DNA particles exhibited initial fast burst release behaviour through a dissolution mechanism, without protecting the DNA secondary structure. However, the magnitude of DNA release was controlled and controlled release systems were achieved by changing the LS/PS ratio in the protein solution where particles were formed. The observed differences in DNA release can be explained by differences in protein-DNA complexation in these systems. As shown in Fig. 4, the protein-DNA ratio increased strongly from the pure LS system to the pure PS system. The stoichiometries obtained would appear to confirm that the presence of PS favours the formation of solid particles.

Although proteins are thought to be biocompatible and nontoxic-compounds, the results of our safety evaluation with the established 3T3 and HeLa cell lines indicated that, as with other cationic derivatives, LS and PS displayed concentration-dependent toxicity towards cells in vitro (Fig. 5). In these experiments, cytotoxicity was determined in the presence of a range of protein concentrations, enabling us to define the protein concentration required to inhibit cell growth by $50 \%$ compared with an untreated control $\left(\mathrm{IC}_{50}\right)$. In the case of $\mathrm{LS}$, its $\mathrm{IC}_{50}$ was found to be higher than $2000 \mu \mathrm{g} \mathrm{mL}^{-1}$ in both cell lines. For PS, it was found to be 140 and $250 \mu \mathrm{g} \mathrm{mL}^{-1}$ for 3T3 and HeLa cell lines, respectively. These differences could be attributed to differences in the binding characteristics of these two proteins, with different total charge and linear charge density: LS is a globular protein that has a net charge of +9 at neutral $\mathrm{pH}$, whereas PS is a highly positively charged linear protein with an overall charge of +21 .

Cell culture studies have greatly increased the understanding of cellular functions and complex signalling pathways and have been routinely used for toxicity screening of new compounds. All cell culture studies hinge on the capacity to maintain a suitable cell culture environment. However, these protocols may be altered by the presence of particles. Previous studies in our laboratory have verified the absorption of the culture media by the particles when 3T3 and Hela cell lines were incubated in the presence of some surfactant-DNA gel particles prepared by the dropwise addition method. In this case, the obtained cell viabilities were close to $5 \%$ (results not published). Although the $\mathrm{IC}_{50}$ values of the corresponding surfactants in solution were not very high (with values around $10 \mu \mathrm{g} \mathrm{mL}^{-1}$ ), this low cell viability may be correlated with the physicochemical properties of these DNA gel particles. Their swelling behaviour could restrict the optimal nutrition and physiological parameters to support the growth of cells.

In was of great interest in this study to characterise these protein-DNA gel particles considering the cytotoxic response they induced. Visual inspection of the corresponding plates exhibited no evident changes on the volume and characteristics of the culture media when 3T3 and HeLa were incubated in the presence of individual protein-DNA gel particles during $24 \mathrm{~h}$. Although these particles are several magnitudes larger than cells and cannot be internalised as a whole, this study demonstrates that the physicochemical properties of these protein-DNA gel particles may not affect their cytotoxic characterisation under standard protocols. These protein-DNA gel particles showed cell viabilities higher than $80 \%$ in almost all cases, except in the case of cells incubated in the presence of LSPS85-DNA gel particles (Fig. 6A). These results can be correlated with differences in protein content on these particles, as have been evaluated using the method of Bradford (Fig. 4A). Although the protein-DNA gel particles remain visible on the plates after $24 \mathrm{~h}$ of incubation, the total protein content on LSPS85-DNA gel particles ( $413 \mu \mathrm{g} \mathrm{mL}^{-1}$ of protein) in comparison with comparing with the other systems (amount ranged between 37 and $288 \mu \mathrm{g} \mathrm{mL}^{-1}$ of protein) might explain these differences in proteininduced cytotoxicity from protein-DNA gel particles. Significant differences between the cell viability obtained in the presence of protein-DNA gel particles and the corresponding proteins solutions have been obtained (Fig. 6B).

In this study, small-sized mixed protein-DNA gel particles were prepared for the first time, and their cytotoxicity was evaluated. Although the particle dispersions were studied without further purification, and both free protein and protein-DNA gel particles were present in the obtained dispersions, the cytotoxic responses shown in Fig. 7A were observed to be significantly different to that observed with proteins in solution (Fig. 7B).

This behaviour can be correlated with the capacity of the different protein systems to form weaker or stronger protein-DNA complexes. In the case of the protein-DNA gel particles, it was expected that the higher the degree of complexation, the smaller the amount of protein that would be released in solution, an amount which would be able to interact with the cells and reduce their viability. Determination of the degree of complexation in the different systems showed that it was strongly dependent on the protein composition at which particle formation took place (Fig. 7C). Independently of the cell line, the observed trend in cell viabilities was in agreement with the observed degree of complexation (Fig. 7D).

The observed differences in cytotoxicity between protein-DNA particles prepared by the dropwise addition method and the nebulisation method could be related to differences in the kinetics of dissolution/release profiles. Studies of DNA release from protein-DNA particles formed by the dropwise addition method have demonstrated that these particles can present DNA release profiles of up to $1000 \mathrm{~h}$, confirming the stability of these protein-DNA gel particles (Morán et al., 2009a). In the present study, the stability of these particles in the culture medium was also confirmed. Supported by visual observation, the particles remained 
present in the well plate after $24 \mathrm{~h}$ of incubation. This behaviour and the fact that the observed cytotoxicity was almost independent of the protein composition (see Fig. 6A) corroborate this argument. Although the profiles of dissolution/release of the protein-DNA gel particles prepared by the nebulisation method have not yet been determined, it is expected that smaller particles will show faster dissolution profiles. As a consequence of the protein release, a more composition-dependent cytotoxic response compared with that observed at large-sized particles could be awaited. In the case of these small-sized protein-DNA particles the cytotoxic responses were strongly dependent on the protein composition (see Fig. 7A).

The preparation of the protein-DNA gel particles by the nebulisation method enabled us to obtain particle dispersions in order to evaluate the effect of the concentration (in this study, expressed as protein concentration). Observation of $\mathrm{IC}_{50}$-values showed that the two cells lines were markedly different in sensitivity to the cytotoxic effects of these protein-DNA particles (Fig. 8 and Table 2). Except in the case of the pure systems, which displayed identical cytotoxicity in both cell lines, the tumour cell line HeLa was more sensitive to the deleterious effects of the mixed protein-based particles than 3T3 fibroblasts (significant differences between 3T3 and HeLa for the same conditions are indicated in Table 2 with an asterisk). Consequently, the mixing procedure had a clear modulating effect on the relative cytotoxicity of these systems towards tumour and non-tumour cell lines.

The ability of protein-DNA gel particles to effectively cross biological barriers was evaluated. To this end, PS-DNA particle dispersions were prepared by nebulisation of DNA containing the nucleic acid selective dye acridine orange. After formation, the particle dispersions were filtered by centrifugal concentrators to remove the excess of protein as well as the non-incorporated dye. Although using this procedure some leaking of the dye from the protein-DNA gel particle can be observed, which may permeate through the cell membrane and associate with genomic DNA, to fluoresce, clear differences between the stained HeLa cell controls and the cells exposed to AO-labelled PS-DNA gel particles (Fig. 9B and $9 D$, respectively). These preliminary results indicate cellular uptake and internalisation of these protein-DNA particles, a prerequisite for subsequent DNA delivery.

\section{Concluding remarks}

Mixtures of two cationic proteins, lysozyme (LS) and protamine sulphate (PS) were used to prepare protein-DNA gel particles employing associative phase separation and interfacial diffusion. protein-DNA gel particles prepared by both methods (dropwise addition and nebulisation) were demonstrated to be promising long-term blood-contacting medical devices based on their negligible haemolytic effect. Cytotoxicity studies demonstrated that the protein solutions at the concentration at which particles were prepared induced poor viabilities in 3T3 and HeLa cell lines. However, cytotoxicity towards 3T3 and HeLa cell lines was reduced significantly when administered in the protein-DNA gel particles prepared by dropwise addition method, with cell viabilities higher than $80 \%$. In contrast, the cytotoxic responses induced by smallsized protein-DNA gel particles were strongly dependent on the protein composition, with viabilities ranging between $10 \%$ and $70 \%$. Under these conditions, the tumour cell line HeLa was more sensitive to the deleterious effects of the mixed protein-based particles than 3T3 fibroblasts. Preliminary results indicate cellular uptake and internalisation of these protein-DNA particles, a prerequisite for subsequent DNA delivery.

Several points are of interest in these protein-DNA gel particles: firstly, unlike delivery in an aqueous solution, the cytotoxicity of the protein system can be reduced when the opposite charges between proteins and DNA spontaneously result in complexation due to electrostatic interactions. Secondly, the magnitude of DNA entrapment can be controlled and controlled release systems achieved through the formation of a DNA-protein complex network giving rise to these protein-DNA gel particles. The decrease in cytotoxicity as well as the formation of a releasable high DNA content reservoir renders these protein-DNA gel particles promising protein-based DNA vehicles for use as a nonviral gene delivery system. Current research focuses on the preparation of protein-DNA gel particles using plasmid DNA. Further research on the particle uptake mechanism and the kinetics of drug uptake and retention in the different cell lines will be useful to establish the efficacy of these protein-DNA gel particles for various therapeutic applications.

\section{Acknowledgements}

This work was financially supported by the Projects CTQ200914151-C02-02 and MAT2012-38047-c02-01 from the Spanish Ministry of Science and Innovation. M.C. Morán acknowledges the support of the MICINN (Ramon y Cajal contract RyC 2009-04683).

\section{References}

Abbasi, S., Paul, A., Prakash, S., 2011. Cationic albumin nanoparticles for enhanced drug delivery to treat breast cancer: preparation and in vitro assessment. Cell Biochem. Biophys. 61, 277-287.

Boverhof, D.R., David, R.M., 2010. Nanomaterial characterization: considerations and needs for hazard assessment and safety evaluation. Anal. Bioanal. Chem. 396 953-961.

Bradford, M.M., 1986. A rapid and sensitive method for the quantification of micrograms quantities of protein utilizing the principle of protein-dye binding. Anal. Biochem. 72, 248-254.

Costa, D., Morán, M.C., Miguel, M.G., Lindman, B., 2008. Cross-linked DNA gels and gel particles. In: Dias, R.S., Lindman, B. (Eds.), DNA Interactions with Polymers and Surfactants. Wiley Interscience, New Jersey.

Crespi, C.L., 1995. Xenobiotic-metabolizing human cells as tools for pharmacological and toxicological research. Adv. Drug Res. 26, 179-235.

Davis, M.E., 2002. Non viral-gene delivery systems. Curr. Opin. Biotechnol. 13, $128-131$.

Desfougères, Y., Croguennec, T., Lechevalier, V., Bouhallab, S., Nau, F., 2010. Charge and size drive spontaneous self-assembly of oppositely charged globular proteins into microspheres. J. Phys. Chem. B 114, 4138-4144.

Dobrovolskaia, M.A., Clogston, J.D., Neun, B.W., Hall, J.R.B., Patri, A.K., McNeil, S.E. 2008. Method for analysis of nanoparticle hemolytic properties in vitro. Nano Lett. 8, 2180-2187.

Fröhlich, E., Meindi, C., Roblegg, E., Griesbacher, A., Pieber, T.R., 2012. Cytotoxity of nanoparticles is influenced by size, proliferation and embryonic origin of the cells used for testing. Nanotoxicology 6, 424-439.

Hawkins, M.J., Soon-Shiong, P., Desai, N., 2008. Protein nanoparticles as drug carriers in clinical medicine. Adv. Drug Deliv. Rev. 60, 876-885.

He, M., Zhao, Z., Yin, L., Tang, C., Yin, C., 2009. Hyaluronic acid coated poly(buty cyanoacrylate) nanoparticles as anticancer drug carriers. Int. J. Pharm. 373, $165-173$.

Hillegass, J.M., Shukla, A., Lathrop, S.A., MacPherson, M.B., Fukagawa, N.K., Mossman, B.T., 2009. Assessing nanotoxicity in cells in vitro, WIREs nanomed. Nanobiotechnology 2, 219-231.

Jondeau, A., Dahbi, L., Bani-Estivals, M.H., Chagnon, M.C., 2006. Evaluation of the sensitivity of three sublethal cytotoxicity assays in human HepG2 cell line using water contaminants. Toxicology 226, 218-228.

Kratz, F., 2008. Albumin as a drug carrier: design of prodrugs, drug conjugates and nanoparticles. J. Control. Release 132, 171-183.

Lasic, D., 1997. Liposomes in Gene delivery. CRC Press, Boca Raton, FL.

Ledley, F.D., 1996. Pharmaceutical approach to somatic gene therapy. Pharm. Res $13,1595-1614$

Lesniak, A., Fenaroli, F., Monopoli, M.P., Aberg, C., Dawson, K.A., Salvati, A., 2012 Effects of the presence or absence of a protein corona on silica nanoparticle uptake and impact on cells. ACS Nano 6, 5845-5857.

Li, S.-Q., Zhu, R.-R., Zhu, H., Xue, M., Sun, X.-Y., Yao, S.-D., Wang, S.-L., 2008. Nanotoxicity of $\mathrm{TiO}_{2}$ nanoparticles to erythrocyte in vitro. Food Chem. Toxicol. 46 3623-3631

Lindman, B., Dias, R.S., Miguel, M.G., Morán, M.C., Costa, D., 2009. Manipulation of DNA by surfactants. In: Platikanov, D., Exerowa, D. (Eds.), Highlights in Colloid Science. Wiley-VCH, Weinheim.

Lindman, B., Dias, R.S., Miguel, M.G., Morán, M.C., Costa, D., 2010. DNA-surfactants systems: particles, gels and nanostructures. In: Nanoscience: Colloidal and Interfacial Aspects. CRC Press Taylor \& Francis, Boca Raton, FL.

Lv, Y.H., Chen, X.G., Wang, Q.Z., Wang, Y., Zhang, J., Liu, C.S., Liu, C.G., Meng, X.H., $\mathrm{Yu}, \mathrm{L}$.J., 2007. Synthesis and characterization of chitosan-based biomaterials 
modified with different active groups and their relationship with cytotoxicity. J. Wuhan Univ. Technol.-Mater. Sci. Ed. 22, 695-700.

Martinez, V., Corsini, E., Mitjans, M., Pinazo, A., Vinardell, M.P., 2006. Evaluation of eye and skin irritation of argininge-derivative surfactants using different in vitro endpoints as alternatives to the in vivo assays. Toxicol. Lett. 164, 259-267.

Morán, M.C., Alonso, T., Lima, F.S., Vinardell, M.P., Miguel, M.G., Lindman, B., 2012. Counter-ion effect on surfactant-DNA gel particles as controlled DNA delivery systems. Soft Matter 8, 3200-3211.

Morán, M.C., Pais, A.A.C.C., Ramalho, A., Miguel, M.G., Lindman, B., 2009a. Mixed protein carriers for modulating DNA release. Langmuir 25, 10263-10270.

Morán, M.C., Baptista, F.R., Ramalho, A., Miguel, M.G., Lindman, B., 2009b. DNA gel nanoparticles: preparation and controlling the size. Soft Matter 5, 2538-2542.

Morán, M.C., Miguel, M.G., Lindman, B., 2010. DNA gel particles. Soft Matter 6, 3143-3156.

Morán, M.C., Mitjans, M., Martínez, V., Nogueira, D.R., Vinardell, M.P., 2013. Current directions in DNA gel particles. In: Muñoz-Torrero, D., Cortés, A., Mariño, E.L. (Eds.), Recent Advances in Pharmaceutical Sciences III. Transworld Research Network, Kerala, India.

Morán, M.C., Miguel, M.G., Lindman, B., 2007a. DNA gel particles: particle preparation and release characteristics. Langmuir 23, 6478-6481.

Morán, M.C., Miguel, M.G., Lindman, B., 2007b. Surfactant-DNA gel particles: formation and release characteristics. Biomacromolecules 8, 3886-3892.

Mosmann, T., 1983. Rapid colorimetric assay for cellular growth and survival: application to proliferation and cytotoxicity assays. J. Immunol. Methods 65, 55-63.
Pack, D.W., Putnam, D., Langer, R., 2000. Design of imidazole-containing endosomolytic biopolymers for gene delivery. Biotechnol. Bioeng. 67, 217-223.

Rao, G., Yadava, P., Hughes, 2007. Rationally designed synthetic vectors for gene delivery. J. Open Drug Deliv. J. 1, 7-19.

Rao, S.B., Sharma, C.P., 1997. Use of chitosan as a biomaterial: studies on its safety and hemostatic potential. J. Biomed. Mater. Res. 34, 21-28.

Rhaese, S., Briesen, H., Rübsamen-Waigmann, H., Kreuter, J., Langer, K., 2003. Human serum albumin-polyethylenimine nanoparticles for gene delivery. J. Control. Release 92, 199-208.

Rejman, J., Oberle, V., Zuhorn, I.S., Hoekstra, D., 2004. Size-dependent internalization of particles via the pathways of chathrin- and caveolae-mediated endocytosis. Biochem. J. 377, 159-169.

Robbens, J., Vanparys, C., Nobels, I., Blust, R., Hoecke, K.V., Janssen, C., Schamphelaere, K.D., Roland, K., Blanchard, G., Silvestre, F., Gillardin, V., Kestemont, P., Anthonissen, R., Toussaint, O., Vankoningsloo, S., Saout, C., Alfaro-Moreno, E., Hoet, P., Gonzalez, L., Dubruel, P., Troisfontaines, P., 2010. Eco-, geno-, and human toxicology of bio-active nanoparticles for biomedical applications. Toxicology 269, $170-181$.

Saenger, W., 1984. Principles of Nuclei Structure. Springer-Verlag, New York.

Sambrook, J., Fritsch, E.F., Maniatis, E.F., 1989. Molecular Cloning: A Laboratory Manual. Cold Spring Harbor Laboratory Press, New York.

Venkatesan, P., Puvvada, N., Dash, R., Prashanth Kumar, B.N., Sarkar, D., Azab, B., Pathak, A., Kundu, S.C., Fisher, P.B., Mandal, M., 2011. The potential of celecoxibloaded hydroxyapatite-chitosan nanocomposite for the treatment of colon cancer. Biomaterials 32, 3794-3806. 